\title{
ULTRSTRUCTURAL CHANGES IN THE SPINAL GANGLIA AFTER IMMOBILIZATION OF THE HINDLIMB OF THE ALBINO RAT
}

\author{
By \\ Adel A. Bondok, Ahmed S. Zolfakar* \\ and Mustafa A. Karwad**
}

\author{
From \\ Mansoura Faculty of Medicine, Menoufiya Faculty of Medicine*, Egypt \\ and El-Arab Medical University**, Libya
}

\begin{abstract}
Prolonged bed rest and immobilization of joints for long periods of time are frequently prescribed for intensive care and orthopedic patients. Abundant scientific evidences in the past 50 years have demonstrated that long-term immobilization lead to multiple pathological changes in most organs and systems of the body, with particular in the nervous and musculoskeletal systems. Moreover, critical illness neuropathy with defect in sensory perception is recognized more frequently in intensive care patients due to immobilization and bed rest for long time. The present investigation was, therefore, designed to study the ultrastructural changes in the primary sensory neurons in the dorsal root
\end{abstract}

ganglia of the albino rat after a long period of immobilization of both the knee and ankle joints by using above knee plaster cast. These changes may shed some light on the possible mechanism underlying the immobilization neuropathy and the defect in sensory perception.

Ten adult male albino rats were used in this investigation. The left knee and ankle joints were immobilized, in the resting position, by the application of an above knee plaster cast for 12 weeks. The contralateral right side was used as control. After 12 weeks, the plastar cast was removed and the rats were sacrificed by intracardiac perfusion with a mixture of $2 \%$ paraformaldehyde and $2 \%$ 
glutaraldehyde. The left (experimental immobilized side) and right (control side) lumbar dorsal root ganglia (L4, L5 and L6) were exposed, carefully dissected out, kept in the same fixative overnight and then processed for electron microscopic examination.

Electron microscopic examination of the DRG of the immobilized side revealed that the affected sensory neurons showed aggregation of distorted cytoplasmic organelles with dissolution of Nissl substance and formation of vacuoles of variable sizes. The most noticeable observation was marked hyperplasia of the neurofilaments and dilatation of the rough endoplasmic reticulum.

Changes similar to apoptosis were seen in the nucleus of the affected neurons including abnormal enfolding of the nuclear membrane and fragmentation and condensation of the nuclear chromatin. Nucleolar margination, nucleolar hypertrophy and triple nucleoli were also observed. On the other hand, the cytoplasmic and nuclear changes observed on the immobilized side were not observed in Vol. 39, No. 1 \& 2 Jan., \& April, 2008 the ganglia of the control mobilized side.

Examination of the myelinated axons in the dorsal root ganglia of the immobilized side revealed wide distention of myelin sheaths with splitting of the myelin lamellae and subsequent formation of large vacuoles and vesicular degeneration of myelin. These changes were not observed in the control ganglia.

\section{INTRODUCTION}

Prolonged bed rest and immobilization of joints for long periods of time are amongst the most frequently prescribed therapies for intensive care and orthopedic patients (Allen et al., 1999). Unfortunately, abundant scientific evidence in the past 50 years has demonstrated that this long-term inactivity, elimination of gravity and immobilization lead to multiple pathological changes in most organs and systems of the body generally known as "immobilization syndrome" (Denes, 1996; Okun et al., 2002).

Critical illness neuropathy is an axonal polyneuropathy recognized more 
frequently in intensive care patients due to immobilization (Zifko, 2000). Despite careful nursing and physio. therapy, wasting, myopathy and neuropathy are commonly seen in sedated or comatosed intensive care patients undergoing long-term bed rest. Wiis and Qvist (1999) described four cases of peroneal nerve lesion with drop foot in patients with up to eight weeks of immobilization. Petersen et al. (1999) reported two pediatric intensive care patients with flaccid tetraparesis.

More recently, Fletcher et al. (2003) reported neurophysiologic evidence consistent with critical illness polyneuropathy in more than $90 \%$ of long-stay patients after intensive care unit discharge. The neurological changes due to immobilization are more pronounced in younger than in older ones, indicating that longer periods of immobilization in younger animals lead to a greater degree of harmful effects (Urso et al., 2006). Moreover, in contrast to nerve lesions in adult animals, retrograde neuronal death is accelerated when nerve injury occurs in immature animals such as newborn rats (Bondok and San- sone, 1984-a; Bondok and Sansone, 1984-b; Yip et al., 1984; Devor et al., 1985). Gawish (2004) revealed that long-term immobilization of the rat hind limb resulted in a significant reduction in the cross-sectional area of the sciatic nerve and in the total num. ber of the myelinated nerve fibers.

Searching the literature for any structural changes in the sensory neurons in the dorsal root ganglia that may explain the effects of this immobilization-associated neuropathy revealed only electrophysiologic studies and clinical reports. In the light of the previous investigations on the effects of immobilization and prolonged bed rest, the present investigation was designed to study the ultrastructural changes in the dorsal root ganglia of the albino rat after a long period of immobilization of both the knee and ankle joints by the use of an above knee plaster cast, which is one of the most widely used methods for the immobilization (Coutinho et al., 2002). The cast is popular and inexpensive method for the immobilization. These changes in the dorsal root ganglia may explain the possible mechanism

MANSOURA MEDICAL JOURNAI. 
underlying the immobilization neuropathy.

\section{MATERIAL AND METHODS}

\section{Animals :}

Ten adult male albino rats weighing $285 \pm 28 \mathrm{gm}$ were used in this investigation. The animals were housed in plastic cages, one rat in a separate cage, under controlled environmental conditions, with free access to standard food and water.

\section{Fixation :}

Rats were anesthetized by intraperitoneal injection of chloral hydrate (300 $\mathrm{mg} / \mathrm{kg}$ ) before the immobilization procedure. The knee and ankle joints of the left hind limb were immobilized in a semiflexed position, by the application of an above knee plaster cast for 12 weeks. The contralateral right side was used as a control. After a period of 12 weeks in the plaster cast, the rats were anaesthetized with chloral hydrate. Then the thorax was opened, a cannula was inserted into the left ventricle of the heart, the right atrium was incised and blood was washed out by intracardiac perfusion with $500 \mathrm{ml}$ of normal saline followed by $500 \mathrm{ml}$ of a mixture of $2 \%$ paraforVol. 39, No. 1 \& 2 Jan., \& April, 2008 maldehyde and $2 \%$ glutaraldehyde in $0.1 \mathrm{M}$ cacodylate buffer at $\mathrm{pH} 7.4$.

\section{Obtaining the Specimens :}

An incision was made in the back of the thigh on both the left (immobilized) and right (control) sides and the left and right sciatic nerves were exposed near the greater sciatic foramen. The sciatic nerve was followed to its roots $(L 4,5,6)$ in the intervertebral foramina where the dorsal root ganglia are located. The L4, L5 and L6 dorsal root ganglia were carefully dissected out and kept in the same fixative in the refrigerator overnight.

\section{Processing the Specimens :}

The specimens were rinsed in cacodylate buffer, postfixed with $1 \%$ osmium tetroxide for 2 hours, dehydrated in ascending series of ethanol, cleared in propylene oxide, infiltrated in a mixture of propylene oxide and Epon resin and then embedded in Epon resin. Semithin sections (1 $\mathrm{mm}$ thick) were cut with the ultramicrotome, stained with toluidine blue and examined with a light microscope for orientation and selection of the areas containing nerve cells. Ultrathin sections (70 - $80 \mathrm{~nm}$ ) were cut, dou- 
ble stained with uranyl acetate and lead citrate and examined with a JEOL electron microscope.

\section{RESULTS}

A. CONTROL GANGLIA (MOBILIZED SIDE)

The present observations on the ultrastructure of the control dorsal root ganglia (Figs. 1, 2 and 3) showed that the spinal ganglion neurons had well-organized organelles and a centrally placed nucleus. The cell bodies of the primary sensory neurons appeared surrounded by a layer of satellite cells. The nerve cells appeared separated by bundles of myelinated axons with regularly arranged myelin lamellae.

Nissl substance consisted of wellorganized parallel cisternae of rough endoplasmic reticulum. Free ribosomes were present in small clusters between the cisternae of the endoplasmic reticulum. The mitochondria were randomly distributed. Welldeveloped Golgi apparatus surrounded the nucleus and was associated with numerous vesicles. The neurofilaments and the neurotubules were dispersed throughout the perikaryon around Nissl bodies and the mitochondria.

The nucleus was large, rounded and centrally located. The nuclear membrane had a smooth undulating profile and the nucleus contained uniformly dispersed chromatin granules

B. EXPERIMENTAL GANGLIA (IMMOBILIZED SIDE):

Electron microscopic examination of the dorsal root ganglia 12 weeks after immobilization revealed a spectrum of structural damage ranging from loss of Nissl substance and cytoplasmic degradation of organelles to frank necrosis on the immobilized side (Figs. 4, 5, 6). The most noticeable observation was marked hyperplasia of the neurofilaments, dilatation of the rough endoplasmic reticulum and marked enfolding of the nuclear membrane (Figs. 6, 7, 9, 10, 11).

Frequently, affected primary sensory neurons exhibited perinuclear aggregation of distorted cytoplasmic organelles with dissolution of Nissl substance, increased numbers of

MANSOURA MEDICAL JOURNAL 
neurofilaments, dilatation of the rough endoplasmic reticulum, vacuoles of variable sizes, formation of large peripheral vacuoles, increased number of lysosomes and decreased size of the mitochondria (Figs. 7, 8, 9). Some degenerated neurons were transformed into large electron-dense multivesicular body (Fig. 6). Polysomes appeared dissociated into single free ribosomes and appeared scattered around the neurofilaments and the dilated rough endoplasmic reticulum (Figs. 8, 9). Lamellar bodies, small myelin figures and dense bodies appeared interspersed among the neurofilaments (Fig. 9).

The degenerated neurons appeared engulfed by satellite cells (Figs. 5, 6). The degenerative changes observed in the sensory neurons of the immobilized side were not ob- served in the ganglia of the control mobilized side.

Changes similar to apoptosis were seen in the nucleus of some neurons including abnormal enfolding of the nuclear membrane and fragmentation and condensation of the nuclear chromatin (Figs. 6, 7, 11). In some nerve cells, nucleolar hypertrophy, nucleolar margination and triple nucleoli were observed (Figs. 12 \&13).

Examination of the myelinated axons in the dorsal root ganglia of immobilized side revealed striking ultrastructural alterations. They appeared in the form of wide distention of myelin sheaths of the myelinated nerve fibers with splitting of the myelin lamellae and subsequent formation of large vacuoles and vesicular degeneration of myelin (Fig. 14).

Vol. 39, No. 1 \& 2 Jan., \& April, 2008 
Adel A. Bondok et al ....

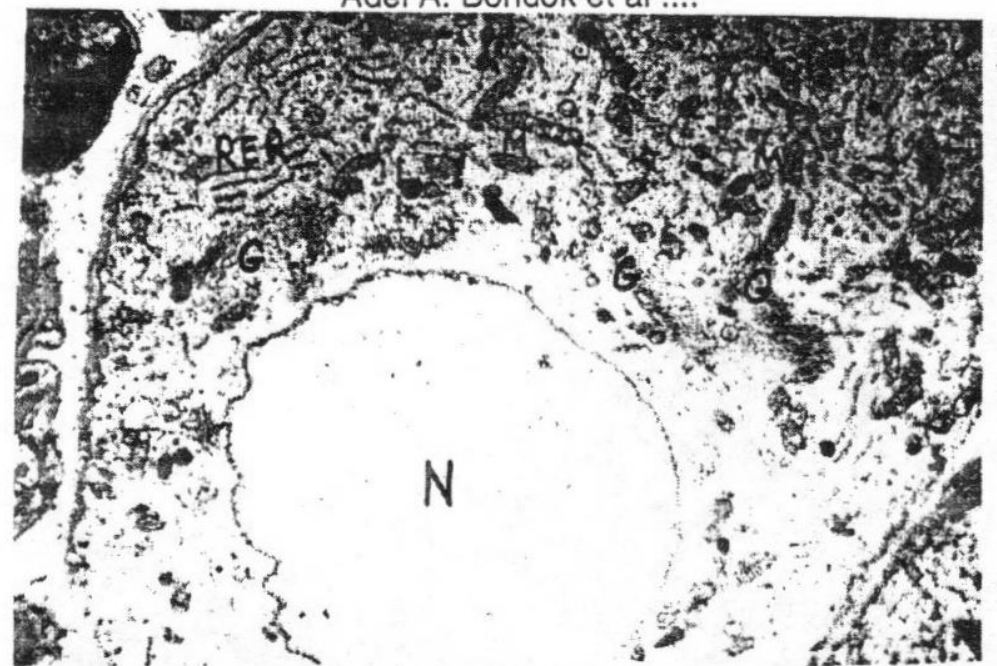

Fig. 1 : Electron micrograph of a control L5 dorsal root ganglion showing a part of sensory neuron containing a rounded nucleus $(N)$, well-organized rough endoplasmic reticulum (RER), Golgi apparatus $(G)$ in the perinuclear zone and randomly distributed mitochondria (M) and lysosomes (L). X 6,000.



Fig. 2 : Electron micrograph of a control L4 dorsal root ganglion showing a part of sensory neuron containing a nucleus $(N)$ with regular nuclear membrane, wellorganized rough endoplasmic reticulum (RER), Golgi apparatus (G) and numerous mitochondria (M). The spaces between the RER and other organelles contain neurofilaments. $\times 5,000$. 
UL TRSTRUCTURAL CHANGES IN THE SPINAL GANGLIA ETC..

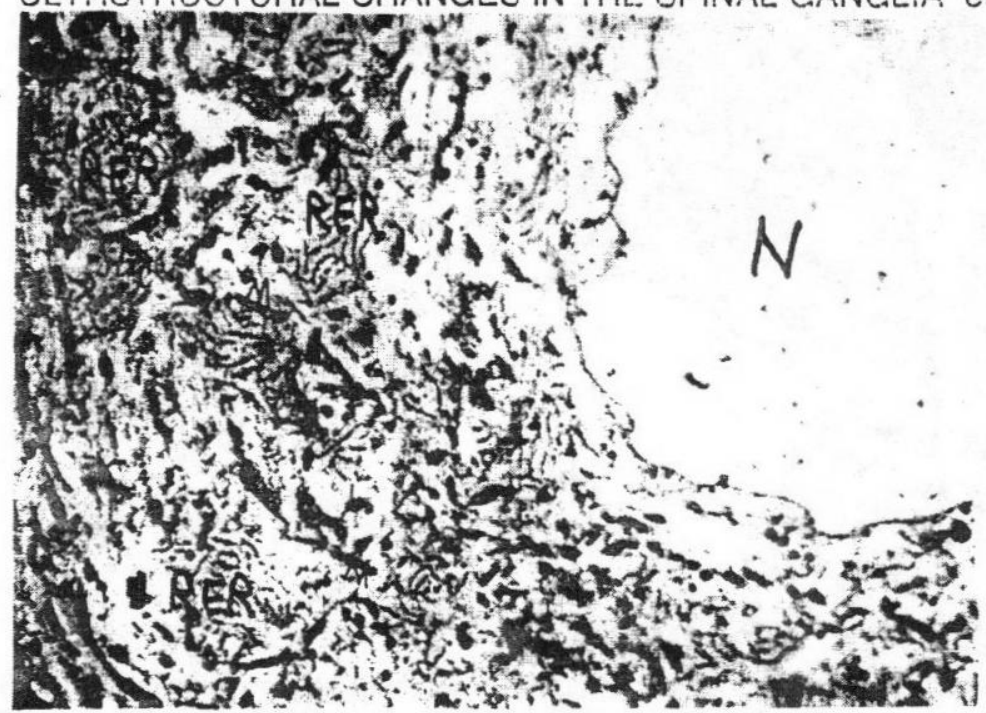

Fig. 3 : Electron micrograph of a control dorsal root ganglion showing a part of sensory neuron containing well-organized rough endoplasmic reticulum (RER), numerous randomly distributed mitochondria $(M)$, other organelles and a nucleus $(N)$ with mild irregularity in the nuclear membrane. Minimal amount of neurofilaments is present between the different organelles. $X 5,000$.

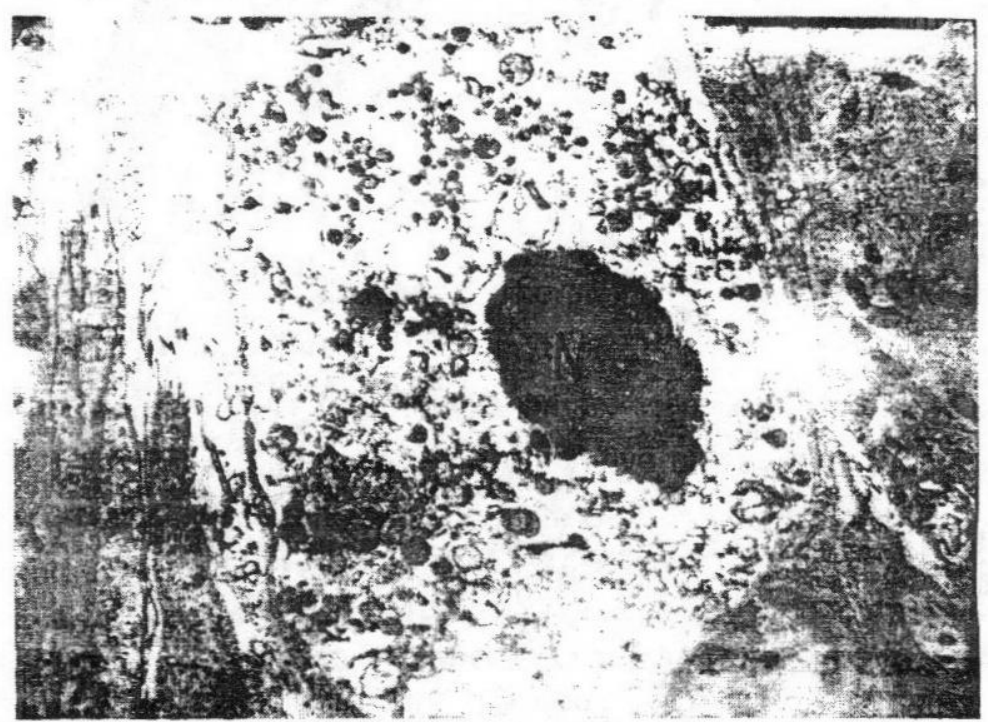

Fig. 4 : Electron micrograph of a dorsal root ganglion 12 weeks after inımobilization showing a completely degenerated neuron containing apoptotic nucleus ( $N$ ) and numerous degenerated organelles. $\times 10,000$. 




Fig. 5 : Electron micrograpin of a dorsal root ganglion on the immobilizedi side showing a completely degenerated neuron ( $\mathrm{N}$ ) engulfed by a satellite cell (S). $\mathrm{X} 5000$

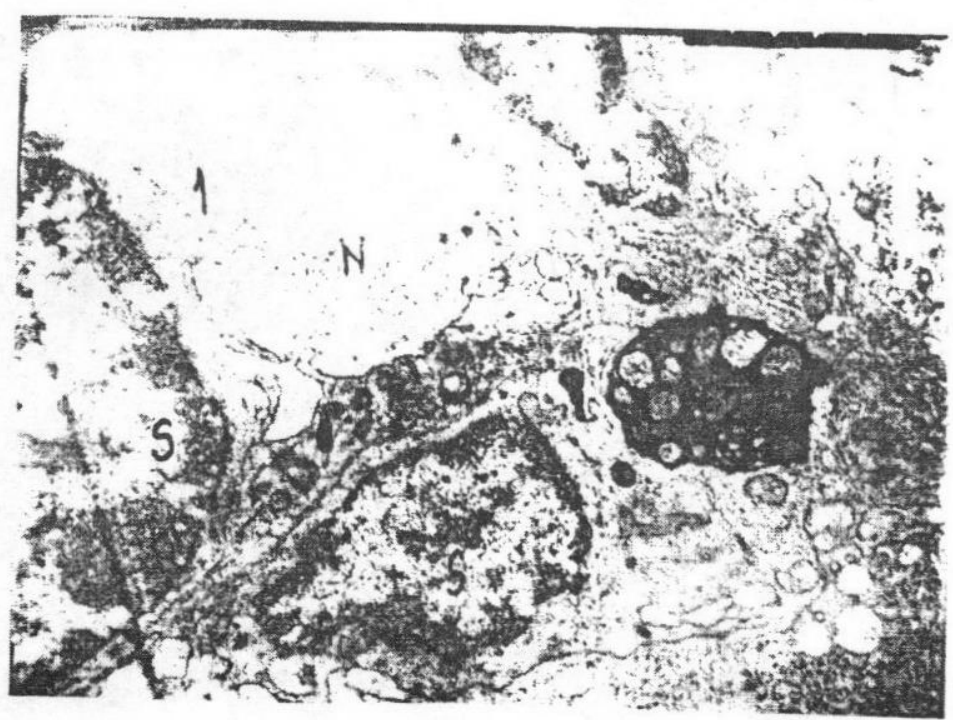

Fig. 6 : Electron micrograph of a dorsal root ganglion 12 weeks after immobilization showing 2 degenerated neurons ( $1 \& 2$ ) engulfed by satellite cells (S). Nerve cell 1 has a nucleus $(N)$ with markedly enfolded nuclear membrane. Nerve cell 2 is transformed into a large mulivesicular body. $\times 10,000$. 




Fig. 7 : Electron micrograph of a dorsal root ganglion 12 weeks after immobilization showing a degenerating neuron containing apoptotic nucleus $(N)$ with large electron-dense mosaic-shaped nucleolus $(\mathrm{Nu})$ and markedly enfolded nuclear membrane $(\mathrm{Nm})$. The cytoplasm contains distorted organelles and dense bodies (arrows). X 11,000.

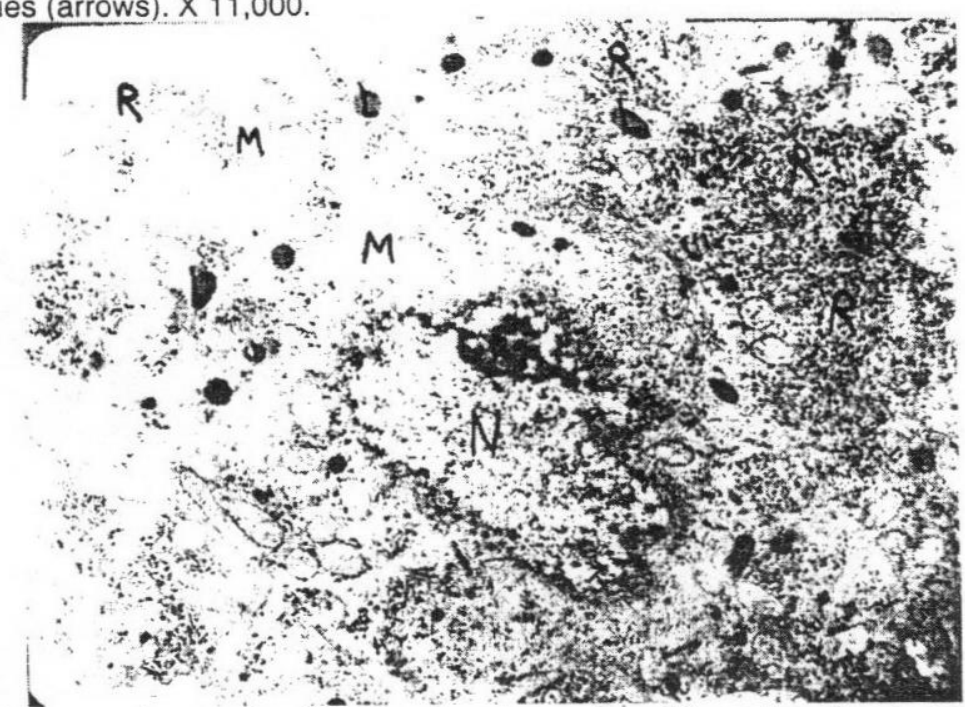

Fig. 8 : Electron micrograph of a dorsal root ganglion 12 weeks after immobilization showing a degenerating neuron containing dissoluted ribosomes $(R)$ from the rough endoplasmic reticulum, degenerated nucleus $(N)$, increased number of lysosomes (L) and distorted mitochondria (M). X 12,000. 




Fig. 9 : Electron micrograph of a dorsal root ganglion 12 weeks after immobilization showing a primary sensory neuron containing dissociated ribosomes $(R)$ from the rough endoplasmic reticulum and their dissolution into free ribosomes, marked increase in the neurofilaments (NF) and myelin figures (My). X 12,000.

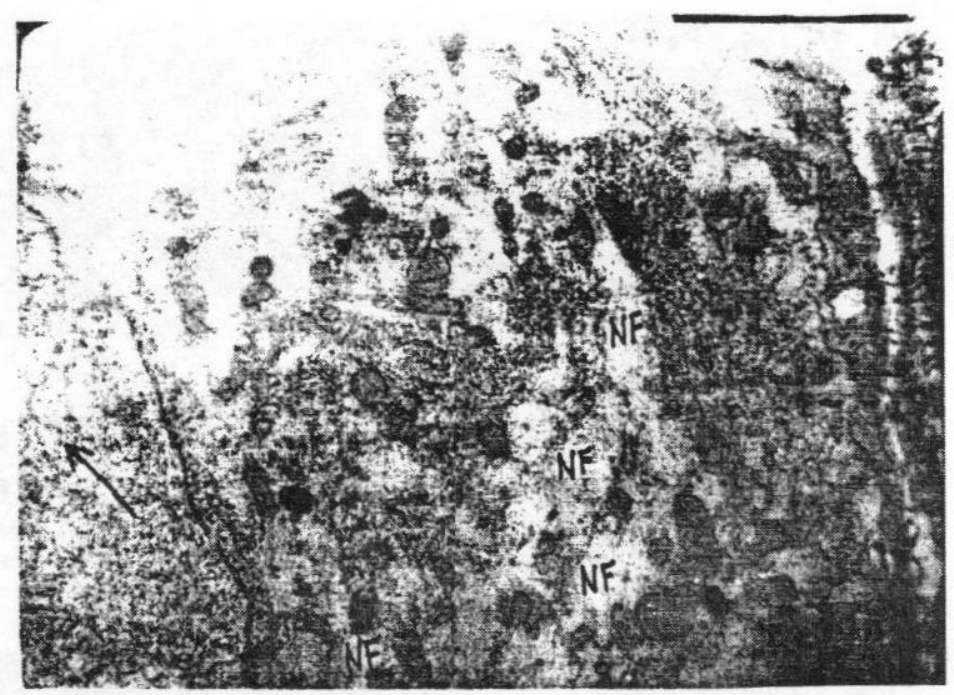

Fig. 10 : Electron micrograph of a dorsal root ganglion 12 weeks after immobilization showing a primary sensory neuron containing marked increase in the neurofilaments (NF) and enfolding of the nuclear membrane (arrow). X 15,000. 
334 ULTRSTRUCTUFIAL CHAINGESIN THE SPINAL GANGLIA ETC.

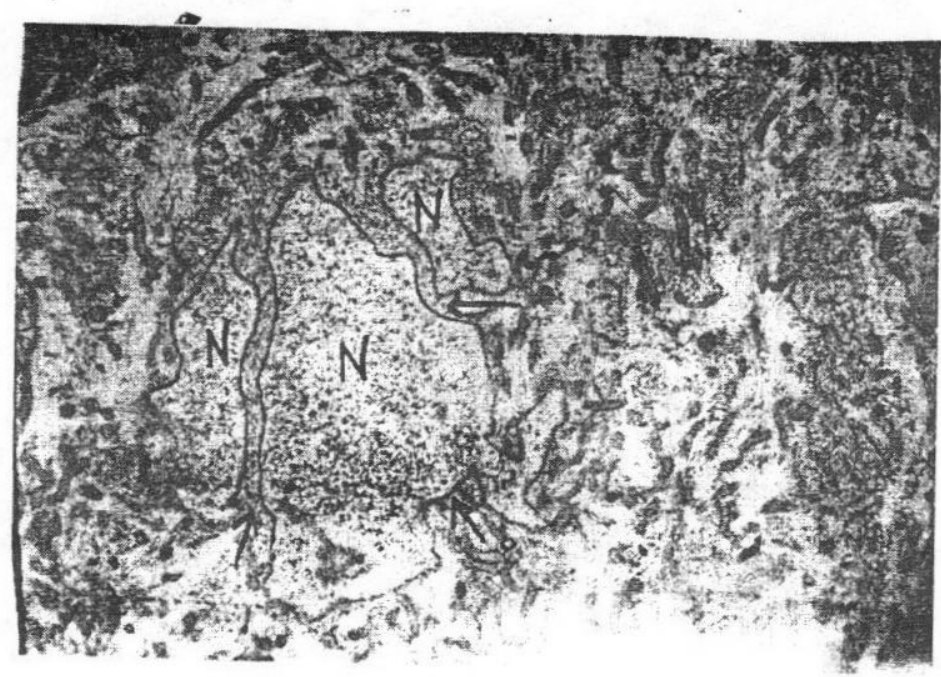

Fig. 11 : Electron micrograph of an afiected primary sensory neuron 12 weeks after immobilization showing a nucleus that appears divided into 3 pieces $(N)$ by marked enfolding of the nuclear membrane (arrows). $\times 9,000$.

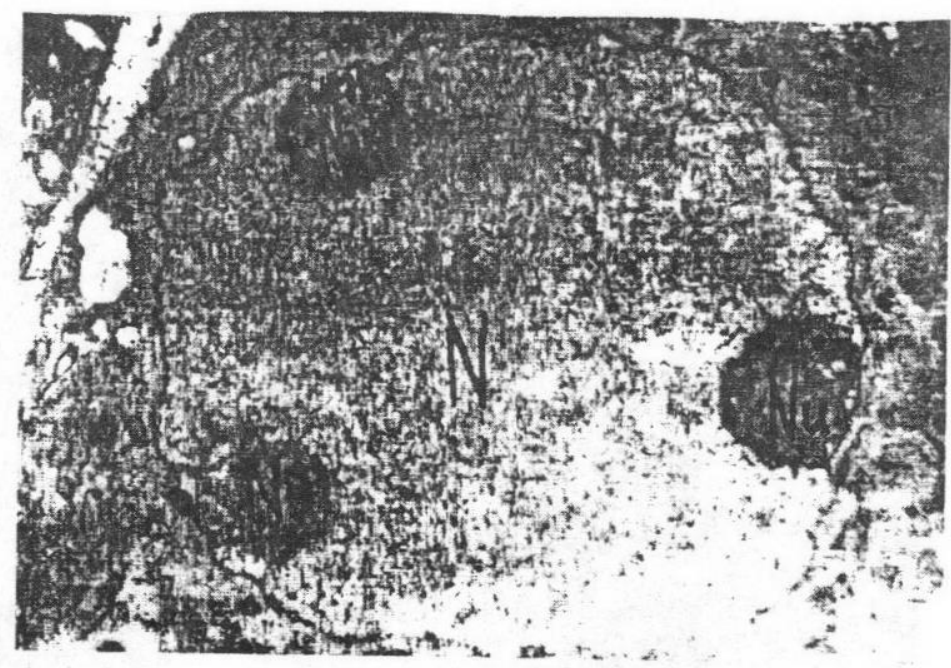

Fig. 12 : Electron micrograph of a sensory neuron 12 weeks after immobilization showing a inucleus $(\mathrm{N})$ containing 3 nucleoli $(\mathrm{Nu})$ which are located at the margin of the nucleus (nucleolar margination) and are attached to the nuclear membrane. $X$ 10,500 .

Vol. 39, No. 1 \& 2 Jari., \& Aprii, 2008 
Adel A. Bondok et ai ....

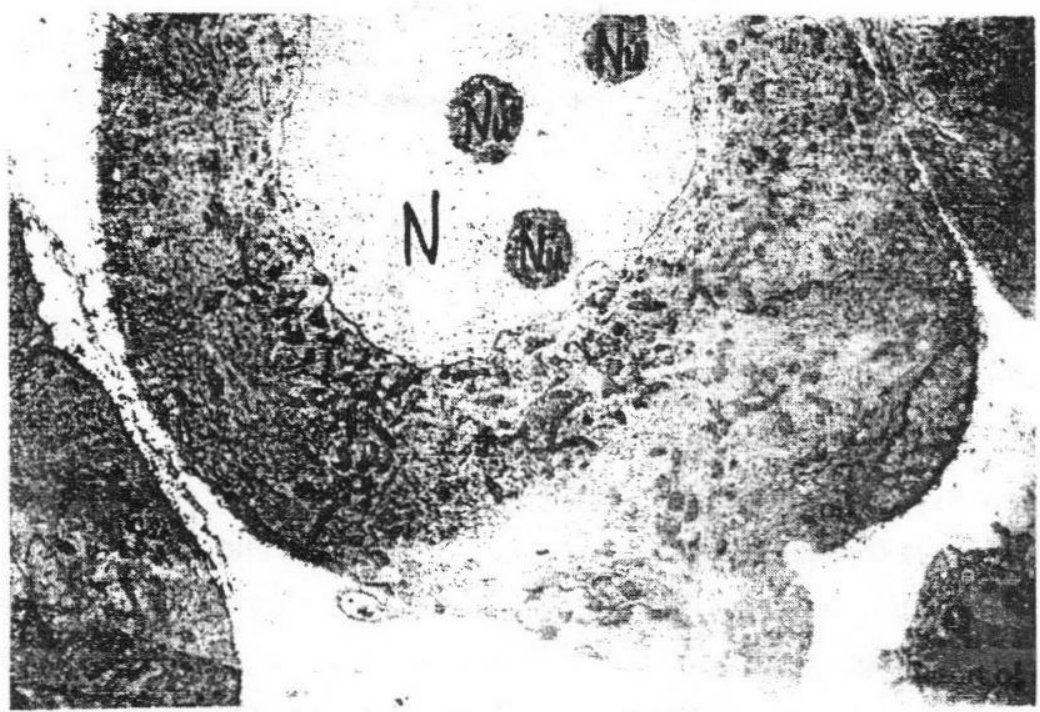

Fig. 13 : Electron micrograph of a sensory neuron 12 weeks after immobilization showing a nucleus $(\mathrm{N})$ containing 3 nucleoli $(\mathrm{Nu}) . \times 4,500$.

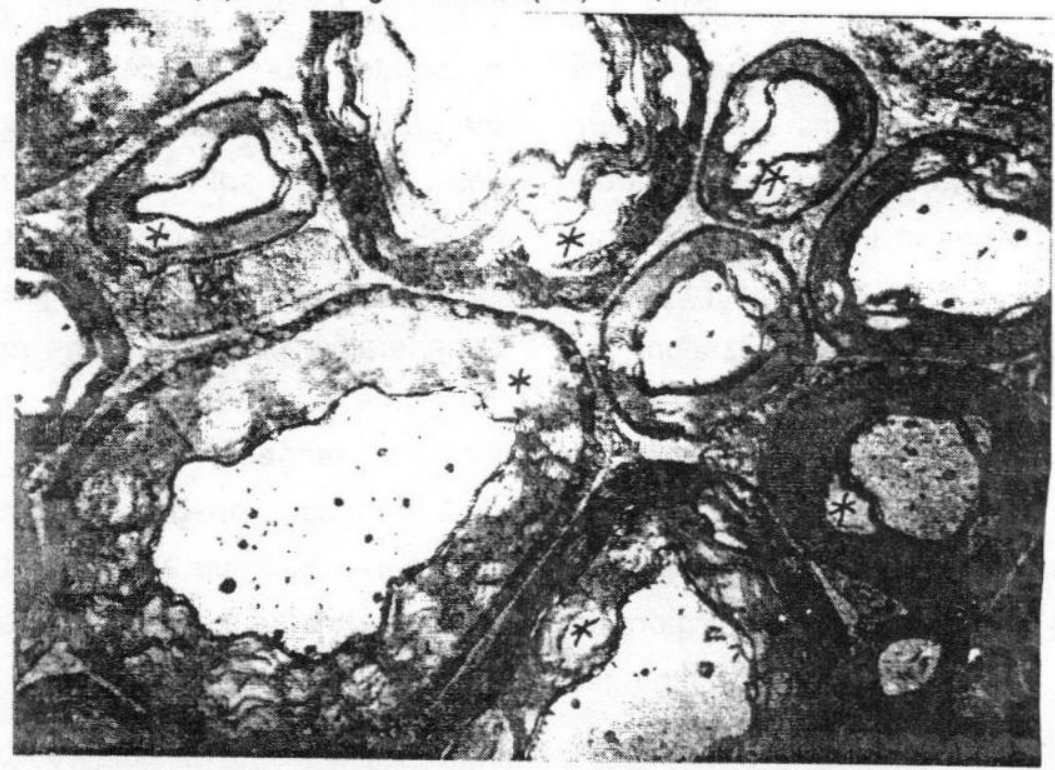

Fig. 14 : Electron micrograph of L5 dorsal root ganglion of the immobilized side 12 weeks after immobilization showing severai myelinated axons. The myelin shows multiple splitting and disruption of the myelin lamellae with formation of vacu. oles ( ${ }^{*}$ ) between the lamellae. $\times 6,000$. 


\section{DISCUSSION}

The effect of immobilization on the structure of the peripheral nervous system is not so clear and has not been fully investigated in the recent literature. At the present time, there is a vague knowledge concerning the structural bases for the immobilization neuropathy syndrome. Searching the literature for any histological evidence that might explain the immobilizationassociated polyneuropathy revealed unly clinical reports and electrophysiologic studies. Almost all the earlier reports on immobilization on the nervous system have dealt only with the clinical manifestations of long-term bed rest. Unfortunately, the ultrastructural changes in the primary sensory neurons which might explain the sensory deficit in the immobilization syndrome have not been investigated. The only available ultrastructural report on the effect of immobilization on the nervous system is that of Gawish (2004) who presented the morphometric and the ultrastructural changes in the sciatic nerve of the albino rat as a model of long-term immobilization.

According to the results of the present investigation and of previous Vol. 39, No. 1 \& 2 Jan., \& April, 2008 investigations (Gawish, 2004), it is obvious that the structural changes in the dorsal root ganglia and in the peripheral nerves could be, in part, responsible for the sensory manifestations of the immobilization neuropathy syndrome.

Gawish (2004) reported that longterm immobilization of the hind limb resulted in dramatic changes in the sciatic nerve in the form of a highly significant reduction in the crosssectional area of the sciatic nerve $(43 \%)$ and in the total number of the myelinated fibers $(33 \%)$. Similar to the present observations, immobilization resulted in splitting of the myelin lamellae, loss of the compact lamellar structure of the myelin sheath and in degenerative changes in the myelin. Therefore, it is reasonable to suggest that the changes in the sensory neurons are most probably due to the degenerative changes and loss of their peripheral branches in the sciatic nerve; a degeneration called retrograde degeneration.

In the present study, long-term immobilization of both the knee and ankle joints for 12 weeks resulted in a 
spectrum of ultrastructural damage to the primary sensory neurons on the immobilized side. The most remarkable observations were marked hyperplasia of the neurofilaments, marked enfolding of the nuclear membrane and dilatation of the rough endoplasmic reticulum. The affected primary sensory neurons showed distorted organelles, numerous lysosomes, dissolution of Nissl substance and formation of vacuoles of variable sizes. Nuclear changes similar to apoptosis were seen in the affected neurons with condensation and fragmentation of the nuclear chromatin. Nucleolar hypertrophy, multinucleoli and nucleolar margination were also observed. Moreover, unusual cytoplasmic inclusions filled with neurofilaments were observed in the affected neurons. Degenerative changes in the myelinated axons in the spinal ganglia of immobilized side with splitting of the myelin lamellae and formation of large vacuoles were observed. These neuronal changes were not observed in the control ganglia of the mobilized control side. The ultrastructural changes after immobilization may indicate a definite structural neural involvement in the immobilization-associated polyneuropathy.

The dissociation of ribosomes from polysomes and rough endoplasmic reticulum to single ribosomes has been also described in degenerating neurons in the facial nucleus of adult mice following facial nerve transection (Torvik and Skjorten, 1971) and in the trigeminal ganglion of adult rats following infraorbital nerve transection (Aldskogius and Arvidsson, 1978). Since the free ribosomes are involved in the production of proteins for local use by the cell and not for transport to the axon terminals, this dissociation into single ribosomes may be a response to increase protein production needed for the survival of cell body.

Abnormal increase in the amount of neurofilaments was a prominent feature of the affected neurons. Similar observations were seen in the spinal ganglia of adult rat after transection of the brachial plexus (Zelena, 1971), in the facial neurons of newborn rabbit after transection of the facial nerve (Torvik, 1972) and in young rats after sciatic nerve crush at birth (Bondok and Gawish, 1994). More recently, the present changes after im-

MANSOURA MEDICAL JOURNAL 
mobilization is almost similar to those reported in the dorsal root ganglia after exposure to neuropathy-inducing organophosphorous compounds (Massicotte et al., 2003).

The presence of nuclear changes similar to apoptosis, nucleolar hypertrophy, multinucleoli and nucleolar margination raise the question of DNA damage. The nucleolar margination is defined as the presence of nucleoli touching the nuclear membrane. Yin et al. (2003) have indicated that the incidence of nucleolar hypertrophy and nucleolar margination is an indication that chronic atrophic gastritis can develop into gastric cancer. Hussein et al. (2003) revealed multinucleation in the irradiated skin cells and that ultraviolet-B irradiation caused an increase in the apoptotic activity and reflecting DNA damage.

The results of the present study are of interest from two points of view. Firstly, they extend our knowledge on the ultrastructure of the retrograde neuronal degeneration. Secondly, they add new information relevant to the reaction of primary Vol. 39, No. 1 \& 2 Jan., \& April, 2008 sensory neurons to immobilization. Disintegration and vacuolation of cell organelles and apoptosis may indicate a stage of "no return" and inevitable cell death.

It is also questionable whether these changes in the nerve cells are primary to immobilization or secondary to the changes in the muscles or the peripheral nerves and whether these changes are reversible or not. Grana et al. (1996) presented evidence that muscle disuse due to cast immobilization of one leg can result in a reversible dysfunction of neuromuscular transmission. On the other hand and more recently, Fletcher et al. (2003) reported persistent neuromuscular and neurophysiologic abnormalities in long-term survivors of prolonged critical illness.

It is concluded in this study that long-term immobilization has a damaging effect on the structure of the primary sensory neurons and subsequently on the sensory perception. These ultrastructural changes after immobilization may indicate a definite structural neural involvement in the immobilization-associated polyneu- 
ropathy. This conclusion supports the lay wisdom "use it or lose it". Therefore, early mobilization and shortening of the period of immobilization and bed rest are highly recommended to avoid structural damage of the peripheral nerves and their associated ganglia. Encourage movement and gentle exercises to improve blood flow to the affected area. Physiotherapy and electrical stimulation of immobilized muscles can prevent many of the complications of inactivity and bed rest.

\section{REFERENCES}

1. Aldskogius, $H$. and Arvidsson, G. (1978) : Nerve cell degeneration and death in the trigeminal ganglion of the adult rat following peripheral nerve transection. J. Neurocytol., 7: $229-250$.

2. Allen, C.; Glasziou, P. and DelMar, C. (1999) : Bed rest: a potentially harmful treatment needing more careful evaluation. Lancet., 354: 1229-1233.

3. Bondok, A. A. and Gawish, S.
(1994) : Electron microscopic study of vacuolar and neurofibrillary retrograde degeneration of primary sensory neurons after sciatic nerve crush in newborn rats. Egypt. J. Anat., 17: 415 - 429.

4. Bondok, A. A. and Sansone, F. M. (1984-a) : Retrograde and transganglionic degeneration of sensory neurons after a peripheral nerve lesion at birth. Exp. Neurol., 86: $322-330$.

5. Bondok, A. A. and Sansone, F. M. (1984-b) : Ultrastructural stereology of synapses in nucleus dorsalis after a peripheral nerve injury at birth. Exp. Neurol., 86: 331 - 341.

6. Coutinho, E.L.; Gomes, A.R.; Franca, C.N. and Salvini, T.F. (2002) : A new model for the immobilization of the rat hind limb. Brazilian Journal of Medical and Biologi- 
cal Research, 35: 13291332.

7. Denes, Z. (1996) : The immobilization syndrome. Orv. Hetil., 137: 1739-1743.

8. Devor, M.; Govrin-Lippmann, R.; Frank, I. and Raber, P. (1985) : Proliferation of primary sensory neurons in adult rat dorsal root ganglion and the kinetics of retrograde cell loss after sciatic nerve section. Somatosensory Res., 3: 139 - 167.

9. Fletcher, S. N.; Kennedy, D. D.; Ghosh, I. R.; Misra, V. P.; Kiff, K.; Coakley, J. H. and Hinds, C.J. (2003) : Persistent neuromuscular and neurophysiologic abnormalities in long-term survivors of prolonged critical illness. Crit. Care Med., 31: 1012 1016.

10. Gawish, S.A. (2004) : Morphometric and ultrastructural changes in the sciatic nerve of the Albino rat after a long period of immobilization of the knee and ankle joints. The Egyptian Journal of Histology, 27: 111 - 127.

11. Grana, E.; Chiou-Tan, F. and Jaweed, M. (1996) : Endplate dysfunction in healthy muscle following a period of disuse. Muscle Nerve, 19: 989-993.

12. Hussein, M. R., Hassan, M. and Wood, G. S. (2003) : Morphological changes and apoptosis in radial growth phase melanoma cell lines following ultraviolet-B irradiation. American Journal of Dermatopathology, 25: 466472.

13. Massicotte, C.; Jortner, B.S. and Ehrich M. (2003) : Morphological effects of neuropathy-inducing organophosphorus compounds in primary dorsal root ganglia 
cell cultures. Neurotoxicol., 24: 787-796.

14. Okun, M. S.; Nadeau, S. E.; Rossi, F. and Triggs, W. J. (2002) : Immobilization dystonia. J. Neurol. Sci., 201: 79-83.

15. Petersen, B.; Schneider, C.; Strassburg, H. and Schrod, L. (1999) : Critical illness neuropathy in pediatric intensive care patients. Pediatr. Neurol., 21: 749753.

16. Torvik, A. (1972) : Phagocytosis of nerve cells during retrograde degeneration: an electron microscopic study. J. Neuropath. Exp. Neurol., 31: $132-146$.

17. Torvik, A. and Skjorten, F. (1971) : Electron microscope observations on nerve cell regeneration and degeneration after axon lesion: I. changes in nerve cell cytoplasm. Acta Neuropath. , 17: $248-264$.

18. Urso, M. L.; Clarkson, P. M. and Price, T. B. (2006) : Immobilization effects in young and older adults. European Journal of Applied Physiology, 96: 564 - 571.

19. Wiis, J. and Qvist, J. (1999) : Peroneal nerve paresis after long-term bed rest in intensive care patients. Ugeskr. Laeger., 161: 4641. 4642.

20. Yin, G.Y.; Zhang, W.N.; Shen, X.J.; Chen, Y. and $\mathrm{He}$, X.F. (2003) : Ultrastructure and molecular biological changes of chronic gastritis, gastric cancer and gastric precancerous lesions: a comparative study. World J. Gastroenterol. , 9: 851-857.

21. Yip, H. K.; Rich, K. M.; Lampe, P. A. and Johnson, E. M. J. (1984) : The effect of nerve growth factor and its MANSOURA MEDICAL JOURNAL 
ULTRSTRUCTURAL CHANGES IN THE SPINAL GANGLIA etc..

antiserum on the postnatal development and survival after injury of sensory neurons in rat dorsal root ganglia. J. Neurosci., 4: 2986 2992.

22. Zelena, J. (1971) : Neurofilaments and microtubules in sensory neurons after peripheral nerve section. $Z$. Zellforsch., 117: 191 - 211.

23. Zifko, U. A. (2000) : Long-term outcome of critical illness polyneuropathy. Muscle and Nerve, Suppl., 9: 4952. 


\title{
الملاخص العربي \\ التغيرات التركيبية فائقة الدقة بالعقد العصبية الشوكية بعل تثبيت الطرف الرخلفى للجرذان البيضاء
}

\author{
عادل عباس بندق - أحمل سعيد ذوالفقار \\ ** مصطفى عبد السلام كرواد \\ كلية طب المنصورة - كلية طب المنوفية"- كلية طب العرب الطبية
}

\begin{abstract}
إن عدم الحـركة لفتـرات زمنية طويلة وكذلك الراحسة السـريرية الطويلة يستخـدمـان بطريقة ثـائعـة لمرضى العناية المركـزة ولمرضى العظام. وهذا يؤدى إلى العـديد من التــــــرات المرضـيـة فى معظم أعضاء وأجهزة الجسم خاصة الجهاز العصبى والجهاز الحركى.
\end{abstract}

ولذلك فقد صمـمت هذه الدراسة لبحث التغيـرات التركيبية فائقة الدقة بالخـلايا العصبية الحسية الأولية فى العقد العصبية للجدر الخلفى للعصب الشوكى للجرذان البيضاء بعد تثبيت الطرف الخلفى الأيسـر لمدة طويلة ويشـمل تثبـيت مـفــلى الكاحل (رسيغ القـدم) والركبـة وذلك باسـتخـدام قـالب جبس يمتد حتى أعلى مـفصل الركبـة. وهـذه التغـيـرات ريما تسلط الضـوء على طريقة حـوث الاعتلال العصبى الطرفى المتعدد المصاحب لعدم الحركة وكذلك سبب الخلل فى باسى الإدراك الحسى.

استخدم فى هذا البحث عشـرة ذكور من الجـرذان البيضـاء البـالغة. تم تثبيت مفصلى الكاحل والركبة بالطرف الخلفى الأيسر لملدة اثنى عشـر أسبوعا باستخدام قالب جبس امتـد حتى أعلى مفصل الركبة واستخدمت الجهة اليمنى المتحركة كجهة ضابطة. ويعد مضى إثنى عشر أسبوعا تم إزالة قالب الجبس وتم التضحية بالجرذان بحقنها بالقلب بنصف لتر من محلول ملح طبيعى لغسل الدورة الدموية تتبعه نصف لتر من محلول مثبت مكون من خليط من r\% بارافورمالدهايد

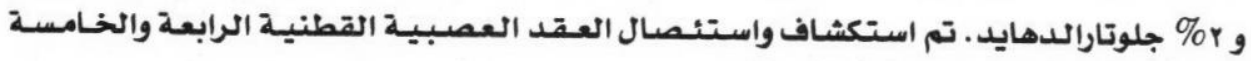
MANSOURA MEDICAL JOURNAL 
والسادسة لكل من الجهة اليسرى المثبتة والجهة اليمنى المتحركة (الضابطة) وتم وضعهم فى نفس المثبت بالثلاجـة لمدة ليلة واحدة وتم تجهيزهم للدراسـة بالمجهـر الإلكترونى. تم تقطيع العينات قطاعات فائقة الرقة وصبغت صبباغة مزدوجـة بأسيتـات اليورانيوم وستـرات الرضاص وتم فحص التفيرات فائقة الدقة بالمجهر الالكترونى.

أظهر فحص العقد العصبية الشوكية بالمجهر الالكترونى بعد اثنى عشر أسبوع من التثبيت أن الخلايا العصبية الحسية الأولية المتضررة ظهر بها تشوه بالجسيمات الحية وتحلل باجسام نسل وتكوين فجـوات ذات أحسام مـختلفة وظهـرت أجسام مـتعددة الطبـات وتركيبـات فمديه وأجسـام داكنة بين الشعيرات العصبية. وكانت الملاحظة الأكثر وضوحا هى زيادة غير عادية فى الشعيرات العصبية وانتفـاخ بخزانات الشبكة الاندويلازمية المحببة. وظهرت أجسام سيتوبلازمية ميتة على شكل كرات من الشعيرات العصبية المتلاصقة.

وشوهدت تغيرات مشابهه لموت الخلية المبرمجر بنواة الخلايا العصبية المتضردة ثـملت انثناءات بغلاف النواة ميع تجزئ وتكثف لكرومـاتين النواة. ولم تلاحظ مثل تلك التغيرات بنواة وسيتوبلازم العقد العصبية الضابطة بالجانب الأيمن المتحرك.

أظهر فحص المحاور العصبية المغمدة بالعقد العصبية بالجانب المثبت وجـود إنتفاخات واسعة

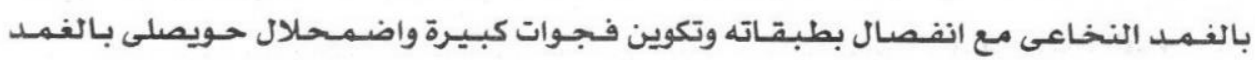
النخاعى.

ولقد استتتج من هذه الدراسـة أن عدم الحـركة لفترة طويلهة له تاثير ضـار على تركيب الخـلايا العصبيـة الحسية الأولية وبالتالى على الإدراك الحسى . ومن المؤكد إن هذه التفيرات التركيبية فائقة الدقة التى نتجت عن عدم الحركة لها دور مؤثر فى حدوث إعتلال الأعصاب الطرفية المتعدد والمصاحب لعـدم الحـركة ولذلك توصى هذه الدراسـة بـتقليل فتـرة عدم الحـركة أو الحـركة المبكرة وكذلك تقليل الراحة السريرية بقدر المستطلاع.

Vol. 39, No. 1 \& 2 Jan., \& April, 2008 